\title{
A review of the effects of dietary organic acids fed to swine
}

\author{
Mocherla V A N Suiryanrayna* and J V Ramana
}

\begin{abstract}
Animal production depends on nutrient utilization and if done there is an accelerated momentum towards growth with a low cost to feed ratio Public concern over the consumption of pork with antibiotic residues of the animals fed with antibiotic growth promoters (AGP) has paved the way to use other additives like herbs and their products, probiotics, prebiotics etc. Numerous feed additives are in vogue for achieving this target and one such classical example is the usage of organic acids and their salts. Usage of organic acids was in progress for over four decades. Early weaned piglets are (3-4 weeks age) exposed to stress with a reduced feed intake, little or no weight gain. This post weaning lag period is due to a limited digestive and absorptive capacity due to insufficient production of hydrochloric acid, pancreatic enzymes and sudden changes in feed consistency and intake. Lowering dietary pH by weak organic acids was found to overcome these problems. The main activity of organic acids is associated with a reduction in gastric pH converting the inactive pepsinogen to active pepsin for effective protein hydrolysis. Organic acids are both bacteriostatic and bactericidal. Lactic acid has been reported to reduce gastric $\mathrm{pH}$ and delay the multiplication of an enterotoxigenic $E$. coli. These acids are the intermediary products in Kreb's cycle and thus act as an energy source preventing the tissue breakdown resulting from gluconeogenesis and lipolysis. Excretion of supplemental minerals and nitrogen are minimized with organic acids as these form complexes with minerals and aids for their bio-availability. Short chain fatty cids like acetic, propionic and n-butyric acid produced by microbial fermentation of dietary fibre in the large intestines may increase the proliferation of epithelial cells and have stimulatory effects on both endocrine and exocrine pancreatic secretions in pigs. Organic acids also enhances apparent total tract digestibility and improves growth performance. It is concluded that organic acids and their salts increase the protein utilization especially in weaner pigs and improves production indices.
\end{abstract}

Keywords: Chelation, Improved productivity, Organic acids, Pathogen inhibition, Protein utility, Swine

\section{Background}

When the basal liquid milk diet is reduced and the stage where in the piglets turn into solid diet of creep ration, the digestive physiology changes where in the intervention of different feed additives is needed to have the maximum nutrient utilization. Gastro-intestinal disturbances during pre and post weaning conditions cause large economic losses in pig industry. The weaning transition is a complex period during which the piglets have to cope up with abrupt separation from their mother, mixing with other litters in a usually new environment and turning over to a less digestible solid creep feed to highly digestible liquid milk. The situation remains same

\footnotetext{
* Correspondence: mv_an.surya@yahoo.co.in

Livestock Research Station, Sri Venkateswara Veterinary University, Garividi- 535 101, Vizianagaram District, Andhra Pradesh, India
}

when the new born piglets are offered with solid creep feed from the 10th day after birth. Weaning exacerbates the level of general stress in these immature animals [1].

It was reported that $50 \%$ of weaned piglets consume their first meal within $24 \mathrm{~h}$ post weaning, $10 \%$ have not eaten until more than $48 \mathrm{~h}$ [2]. and thus the energy requirements for maintenance are only met 3 days post weaning and it takes 8-14 days for piglets to recover their pre-weaning level of energy intake [3].

Intensification of swine rearing paved the way for better productive performance and this has led to the shortening of the suckling period of piglets from the usual 6 weeks to 3-4 weeks of age in order to maximize annual sow productivity. A complication of early weaning leads to post weaning diarrhoea, which causes retarded growth, increased mortality [4]. In order to check the 
diarrhoea and improve the performance, prophylactic doses of antimicrobial feed additives like antibiotics, and antibiotic like growth promoters are being added to weaner and grower diets. Antibiotics have been used in animal production for over 50 years. Feeding of antibiotics was very successfully adopted and has become an integral point of developing nutritional strategies for all farm animals [5]. Feeding swine with antibiotics has been documented to increase weight gain by $3.3-8 \%$ and improves feed efficiency approximates by $3 \%$ [6]. In recent years public concern over the use of antibiotics which led to the development of resistant pathogen strains and antibiotics residues in animal products and these consequences encouraged to search for alternative means of controlling scours with no hazard to humans.

There was an increased awareness on the ban of using antibiotics to avoid their residues in meat and about the risk developing cross-resistance of pathogens to antibiotics $[7,8]$.

In order to prevent bacterial resistance against antibiotics, like other feed additives, fermented liquid feed (FLF) has been suggested as alternatives [9]. FLF not only reduces the gastric $\mathrm{pH}$ but gives simultaneous provision of feed and water which may result in easier transition from sow's milk to solid feed for the piglets $[10,11]$.

FLF is produced by incubating the feed together with either the water or by product from the food or ethanol production. During the period of incubation fermentative micro organisms produce different organic acids, mainly lactic acid and acetic acid which reduce the gut $\mathrm{pH}$ [12]. Because of it's probiotic properties, FLF is proved better than organic acids. A well fermented feed with lactic acid bacteria is a very cost-effective method to produce organic acids.

Organic acids can be both bacteriostatic and bacteriocidal and these actions depend on the levels of their inclusion. These acids can be effectively used along with other feed additives [13].

Various other feed additives such as organic acids, copper sulphate, zinc oxide, probiotics, prebiotics and herbs have been studied in newly weaned piglets [14-16]. Partanen and Morz Z [17] reported that the inclusion of organic acids in the diet can enhance growth performance and modulate intestinal microbiota in pigs. Lactic acid has been reported to reduce gastric $\mathrm{pH}$ and delay the multiplication of an enterotoxigenic E. coli [18] and to be more effective than other organic acids in improving pig growth performance [16].

When the piglets are weaned earlier at 3-4 weeks of age, they are exposed to both nutritional and environmental stress which often results in reduced feed intake, little or no weight gain and in some instances diarrhoea, morbidity and death. This postweaning lag period is a result of a limited digestive and absorptive capacity due to insufficient production of hydrochloric acid, pancreatic enzymes and sudden changes in feed consistency and intake $[4,19]$. At this age the immunological status of a piglet is also low as passive immunity acquired through maternal colostrum is dramatically decreased, and active immunity is only beginning to develop [20]. Lowering dietary $\mathrm{pH}$ by weak organic acids, such as citric, formic, fumaric, lactic or propionic acids has been reported to be helpful in overcoming problems of the post weaning lag period [21, 22].

Acidifying the feed or water has started way back in 1968 as [23] added $0.8 \%$ lactic acid to drinking water and reported that the growth response and feed efficiency in weaning piglets were significantly improved with a reduction in the haemolytic E. coli counts both in the duodenum and jejunum. Earlier reports [24-26] documented beneficial effects on performance of weaning pigs by adding organic acids or acidifiers. In the present context, the word organic acid is a pure acid and acidifier includes organic acid salts also.

A low $\mathrm{pH}$ in the gut is beneficial in several ways. It will increase the activity of the enzyme pepsin which enhances the utilization of the protein which is good both for the environment and economy of production. Low $\mathrm{pH}$ also increases the digestibility of nutrients through the changes in the villus height and depth in the small intestines in young piglets. This phenomenon can be explained as the protein from milk (casein) needs the pig's stomach to have a $\mathrm{pH}$ of 4 in order to coagulate, precipitate and reach a maximum digestibility of about $98 \%$. But the case of vegetable and fish proteins is different which needs pepsin for maximum efficiency at a desired $\mathrm{pH}$ of $2-3.5$ which is only achieved by organic acids.

Although the organic acid supplementation was initially targeted for weaned piglets, there is growing evidence that dietary acidification may also be beneficial for fattening pigs. The apparent ileal digestibility of protein and amino acids [27-29] and absorption of minerals [30] were improved in fattening pigs by the addition of organic acids. This may contribute not only to improved performance but also to reduced Nitrogen and Phosphorus excretion with decreased environmental pollution. Organic acids are also known as effective preservatives which protect stored feeds against undesirable bacterial or fungal growth [31], and improved quality of feeds over time may further contribute to improved performance. The main action by which acidifiers store feed ingredients is by the way of reducing the $\mathrm{pH}$ of the feeds [17].

The aim of this review is to evaluate the response of weaned piglets, growing pigs and reproductive $\mathrm{m}$ sows to dietary organic acids as illustrated in terms of performance, i.e., growth rate, feed intake and feed utilization. In 
addition, reasons for varying responses to and possible modes of action of organic acids will be discussed.

\section{Methodological review Mode of action of organic acids}

Like antibiotics, organic acids have an antimicrobial activity. The acids can penetrate the bacterial cell wall and disrupt the normal actions of certain types of bacteria including Salmonella spp, E. coli, Clostridia spp, Listeria spp. and some coliforms. Therefore, reduction in numbers of some species of the normal intestinal bacteria as well as pathogenic bacteria can occur in animals fed organic acids. Organic acids are believed to improve overall performance by reducing microbial competition with the pig for nutrients, by lowering the risk of subclinical infections, reducing the intestinal immune response and by reducing the production of harmful bacterial compounds. In a nut shell organic acids lowers gastric $\mathrm{pH}$ $[26,32]$, converts inactive pepsinogen to active pepsin, inhibits pathogenic bacteria proliferation, acts as an energy source in GI-tract, aids in gastric emptying rate enhances endogenous enzyme secretion and chelates minerals [33] which are discussed here under.

\section{Lowering of stomach $\mathrm{pH}$}

The main action of organic acids in poultry is mainly antimicrobial, whereas in pigs, a key activity is reduction of stomach $\mathrm{pH}$ [34]. In the pig, protein digestion begins in the stomach with the action of pepsin, secreted as the enzyme precursor, pepsinogen by stomach mucosa. Conversion of pepsinogen to pepsin occurs rapidly at $\mathrm{pH} 2.0$ but only slowly at $\mathrm{pH} 5.0$ to 6.0. In turn, pepsin works best in an acidic environment, $\mathrm{pH} 2.0$ to 3.5 , and activity declines rapidly above this $\mathrm{pH}$. Carbohydrate hydrolysis in the stomach occurs by the action of salivary amylase, which, in contrast to pepsin, is inactivated once $\mathrm{pH}$ falls to 3.5 .

In the suckling pig, acid secretion is low and the principal source of acidity is bacterial fermentation of lactose from sow's milk to lactic acid. A high level of lactate in the stomach tends to inhibit $\mathrm{HCl}$ secretion. Ingestion of solid feed reduces the level of lactic acid in the stomach and stimulates $\mathrm{HCl}$ production but, in practice, creep feed consumption is low and variable at least up to 4 weeks of age [35]. At weaning, a combination of low acid secretion, lack of lactose substrate, and consumption of large meals at infrequent intervals can result in elevated $\mathrm{pH}$, often to over 5.0 and it may remain high for several days. The high acid-binding/buffering capacity of the feed helps to further raise the stomach $\mathrm{pH}$. Inclusion of whey or lactose in the starter diet ensures continuation of bacterial fermentation and lactic acid production. Development of $\mathrm{HCl}$ secretory capacity occurs more rapidly in the weaned pig than in the suckling pig. [36] reported a reduction in stomach $\mathrm{pH}$ from 4.6 to 3.5 by the addition of $1 \%$ citric acid and from 4.6 to 4.2 by $0.7 \%$ fumaric acid in the diet. On the other hand inorganic acids, such as hydrochloric or phosphoric acid (both of which reduce stomach $\mathrm{pH}$ ), do not improve growth rate or feed conversion of pigs in vivo [37].

Lowering the acid-binding capacity of diets for newlyweaned pigs can help ease the transition from milk to solid food at weaning. Raised stomach $\mathrm{pH}$ after weaning results in reduced digestion of feed which will then be fermented in the hind gut and may provoke diarrhoea. A high gastric $\mathrm{pH}$ will also allow pathogens to survive and allow them greater opportunity to colonise the digestive tract [38].

\section{Inhibition of pathogenic bacteria}

Lactic acid has been reported to reduce gastric $\mathrm{pH}$ and delay the multiplication of an enterotoxigenic E. coli [18] and to be more effective than other organic acids in improving pig performance [16].

Shift from milk diet to solid creep diet in weanling piglets is known to disturb the intestinal microflora balance and may adversely affect the gastro-intestinal functions [39]. It is well known that low $\mathrm{pH}$ in association with rapid flow of digesta can reduce the colonization of microbes in the gastro -intestinal tract [40].

As a matter of fact, animals and plants live in symbiosis with different bacteria, which can protect the host from the colonisation of pathogenic bacteria, regulate the development of the gut or produce vitamins and hormones for the host, while some bacteria are also known to cause diseases. However, the presence of bacteria within the gastro-intestinal tract in general also leads to the competition of the host animal and the bacterial population for nutrients. Bacteria furthermore secrete toxic compounds i.e., toxic amino acid catabolites, decrease fat digestibility, stimulate rapid turnover of absorptive epithelial cells, require an increased rate of mucus secretion by intestinal goblet cells and stimulate immune system development and inflammatory responses. All of these effects lead to impaired growth performance and research has demonstrated that as much as $6 \%$ of the net energy in pig diets is lost to the microflora.

Therefore, it is not only highly important to control possibly harmful bacteria, but also to keep the bacterial population within the gut well balanced. Already a long time ago organic acids were identified to be able to alter the gastro-intestinal microflora by reducing in particular acid-intolerant bacterial species such as E. coli, Salmonella and Campylobacter resulting in increased growth performance. However, it was also shown, that organic acids have stronger effects in the inhibition of grampositive bacteria. This is due to the structural differences of gram-positive and gram-negative bacteria. In general, 
the cytoplasm of the cell is surrounded by the cytoplasmic membrane. The cytoplasmic membrane is covered by a thick cell wall layer mainly consisting of peptidoglycan and adjoined by extracellular polysaccharides, teichoic acids and teichuronic acids. The peptidoglycan layer is significantly thinner in gram-negative bacteria compared to gram-positive bacteria. However, gram-negative bacteria are surrounded by an additional outer membrane which provides the bacteria with an inherent resistance to hydrophobic antibiotics and detergents due to the presence and features of lipopolysaccharides in the outer membrane.

Often organic acids were combined with other naturally derived products such as essential oils in an attempt to use possible synergism to combat pathogenic bacteria. Essential oils in general serve as antioxidants, stimulate the immune system, suppress harmful microorganisms on one side, but stimulate beneficial microbes on the other, by regulating the activity of enzymes especially lipase, which protects the gut villi and interferes with the DNA replication of bacterial cells and therefore have anti-bacterial effects.

When the piglets face a stress on shifting of liquid to solid feed and during weaning, if the stomach $\mathrm{pH}$ is not lowered, coliforms dominate with a reduction in Lactobacilli [41]. It was reported by [42] that acidic conditions in the stomach favour the growth of Lactobacilli which inhibits the colonization and proliferation of E. coli by blocking the sites of adhesion or by producing lactic acid and it's metabolites which lower gastric $\mathrm{pH}$ and thus checks the pathogens. More over organic acids have strong bactericidal properties. Non-ionized organic acids can penetrate the bacterial cells and disrupts the normal physiology of the bacteria [43]. When the undissociated organic acids (Fig. 1) penetrate the bacteria, they get dissociated to $\mathrm{H}^{+}$and anions $\left(\mathrm{A}^{-}\right)$. This action further reduces the internal $\mathrm{pH}$ of the bacteria checking the growth of $\mathrm{pH}$ sensitive Coliforms, Clostridia, Listeria

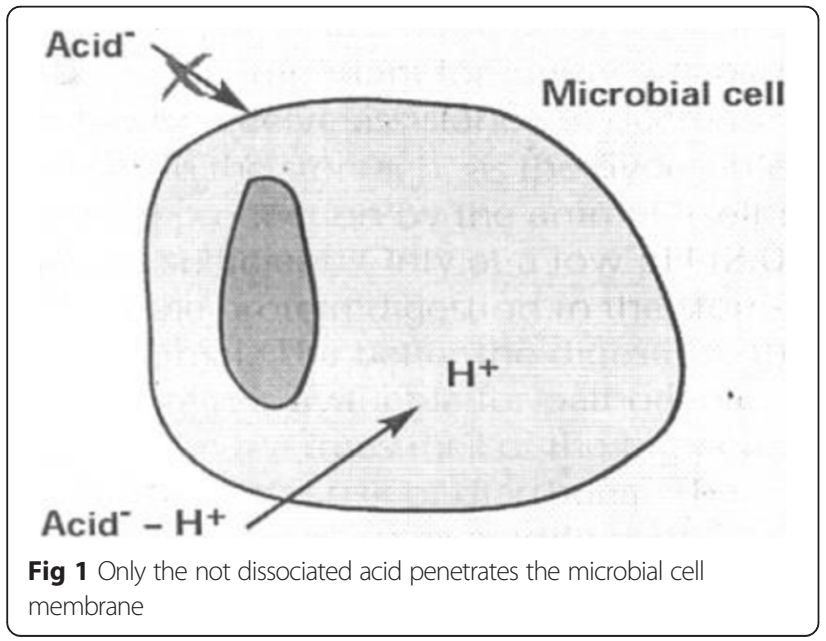

because these bacteria cannot tolerate the broad range of internal $\mathrm{pH}$ in the bacteria and external stomach $\mathrm{pH}$. On the other hand, the non-pH sensitive bacteria like Lactobacilli and Bifidibacterium spp. can tolerate [44] these variations in the internal and external $\mathrm{pH}$. Nondissociated organic acids are not absorbed by the intestinal epithelium.

Organic acids are both bacteriostatic and bactericidal. As undissociated organic acids are lipophilic, they can cross the cell membrane of gram negative bacteria, such as Salmonella. Once inside the cell, the higher cytosolic $\mathrm{pH}$ causes the acid to dissociate, releasing hydrogen ions, which consequently reduces the intracellular $\mathrm{pH}$. Microbial metabolism is dependent on enzyme activity, which is depressed at lower $\mathrm{pH}$. To redress the balance, the cell is forced to use energy to expel protons out across the membrane via the $\mathrm{H}^{+}$- ATPase pump to restore the cytoplasmic $\mathrm{pH}$ to normal. Over a period of exposure to an organic acid, this can be sufficient to kill the cell [13].

It was reported that acidifiers improve gut health by promoting the beneficial bacterial growth while inhibiting the growth of pathogens through the reduction of $\mathrm{pH}$ and buffering capacity of the diets. The reduced buffering capacity of the diets containing organic acids reduces the colonization of undesirable microbes [45-48].

Salmonella enteritica Typhimurium is the predominant serotype found in pig carcasses in Europe, accounting for about $71 \%$ of cases. Several serotypes are resistant to antibiotics, which has put pressure on producers to prevent contamination. While Salmonella cannot be wholly eradicated in pig units, it can be controlled to minimise the risk to consumers. Although heat treatment is effective in reducing contamination of feed leaving the feed mill, this effect does not persist during transport, storage and subsequent out feeding. When conditions within the feed are less conducive to bacterial infection, Salmonella contamination can be reduced. The next critical control point is within the pig's gut, where conditions for bacterial growth may again be optimal. Salmonella growth is favoured at moisture content greater than $12 \%$ and a pH between 4.5 and 9.0. It is no coincidence that the pig gut can provide Salmonella everything they need to thrive [49].

\section{Energy source}

Organic acids act as an energy source in the gut of pigs as these are the intermediary products of tricarboxylic acid and thus helps in preventing the tissue breakdown resulting from gluconeogenesis and lipolysis [50]. It was reported by [32] that the growth promoting effects of the organic acids were due to their energy values. Kirchegessner and Roth [51] suggested that pigs can utilise fumaric acid as energy source as efficient as glucose. Blank et al. [52] reported that there is a possibility that fumaric 
acid as a readily available energy source may have a local trophic effect on the mucosa in the small intestines and lead to an increase in the absorptive surface and capacity in the small intestines due to faster recovery of the gastrointestinal epithelial cells after weaning.

\section{Mineral utilization}

Organic acid anions can complex with calcium, phosphorus, magnesium and zinc, improving the digestion of these minerals and reducing the excretion of supplemental minerals and nitrogen. The effects of organic acids on phytate $\mathrm{P}$ utilization might result from a change to the $\mathrm{pH}$ of the gastrointestinal tract to a $\mathrm{pH}$ more favorable for phytase to hydrolyze phytate [53]. Kirchegessner and Roth [51] reported that the apparent absorption and retention of Calcium, Phosphorus and Zinc were improved by the addition of fumaric acid. A decrease in intestinal $\mathrm{pH}$ is favourable for the P solubility $[54,55]$ and it was reported that the microbial phytase is more active at lower $\mathrm{pH}$ and thus addition of organic acids indirectly helps in P absorption. Boling et al. [56] suggested that citric acid improved phytate P utilization by competitively chelating Calcium, reducing the formation of insoluble Ca-phytate complexes. The intensity with which the organic acids work depends upon the type of diet and the dietary mineral content. In pigs fed with suboptimum levels of Zinc, addition of $15 \mathrm{~g}$ of citric acid per $\mathrm{kg}$ feed did not show the symptoms of parakeratosis $[57,58]$ but no significant effects on the apparent absorption and retention of zinc or other minerals (Ca, P, $\mathrm{Mg}, \mathrm{Fe}, \mathrm{Cu}$ and $\mathrm{Mn}$ ) were found.

\section{Endogenous enzyme secretion and gut morphology}

It was reported that short chain fatty acids have stimulatory effects on both endocrine and exocrine pancreatic secretions in pigs. The natural acids like $\mathrm{HCl}$ in the stomach can get a pH of 1.3 where as the lactic acid produced from lactose in sow's milk is able to produce a $\mathrm{pH}$ of 3.8 [59]. Above this $\mathrm{pH}$, serum secretin levels decrease. Intestinal acidification either with $\mathrm{Hcl}$ or monocarboxylic acids or organic acids elevates serum secretin content. Both pancreatic exocrine secretion and biliary excretion are stimulated by the release of secretin [59]. Pancreatic exocrine response by monocarboxylic acids was highest for formic acid followed by lactic acid, pyruvic acid, acetic acid, butyric acid and propionic acid. As shown by [60, 61], short chain fatty acids such as acetic, propionic and n-butyric acid produced by microbial fermentation of dietary fibre in the large intestines may increase the proliferation of epithelial cells. Overland et al. [62] demonstrated an increase in the length of the microvilli in the ileum and the depths of the crypts in the caecum in growing pigs when fed with $0.17 \%$ of Sodium butyrate and thus the gut morphology is changed. Increased epithelial cell proliferation has also been observed when short chain fatty acids are given orally or by intravenous injections or gastro-intestinal infusion [61] as dietary organic acidifiers can influence fermentation patterns in the small intestines. Other studies have demonstrated that addition of dietary organic acids in pigs stimulates secretion via metabolic enzyme activity. Butyric acid for instance, is the main energy source for the epithelial cells of the large intestine and is considered to be effective for promoting epithelial growth [62].

\section{Performance and nutrient utilization}

Effective dietary doses of organic acids have been established [63] that can improve productivity of pigs to levels comparable with antibiotic growth promoters. Overland et al. [64] added 0.8 or $1.2 \%$ potassium diformate to diets for primiparous and multiparous sows from one mating lactation. The performance of the piglets of these sows was also recorded and compared. The authors found that sows fed potassium diformate had increased back fat thickness during gestation, although daily feed intake and body weight gain did not change. Feeding potassium diformate also tended to be associated with a heavier birth weight of piglets, irrespective of dose. It also improved average daily gain, resulting in a greater weaning weight. Sows fed the diets containing potassium diformate tended to have increased milk fat content on day 12 post-farrowing. On the other hand, sows fed potassium diformate at a dosage of $0.8 \%$ under tropical conditions [65] tended $(P<0.1)$ to have a higher feed intake from 3 days after farrowing. Furthermore, reduced weight loss $(P=0.06)$ during the weaning period and lower back fat loss $(P=0.05)$ was observed.

Addition of sodium format to grower diets at $0.9 \% \mathrm{im}$ proved [67] the ADG (g) and feed: gain ratio $(P<0.05)$ but not in finisher pigs. They reported that $\mathrm{CP}$ and $\mathrm{DM}$ digestibility were higher $(P<0.05)$ for grower cross-bred pigs supplemented with $0.9 \%$ sodium format. Falkowski and Aherne [21] demonstrated that ADG (g) was 4 to $7 \%$ greater and feed conversion ratio was also improved 5 to $10 \%$ when fumaric or citric acid was provided to pigs weaned at 4 weeks age. Giesting and Easter [50] reported that addition of graded levels of fumaric acid at 0, 1, 23 and $4 \%$ resulted in a linear increase in gain:feed, daily gain regardless of dietary protein level. It was reported by Blank et al. [52] that dietary inclusion of fumaric acid improved the ileal digestibility of $\mathrm{CP}$, gross energy and some amino acids. On the contrary, [68] reported a negative effect on ileal digestibility of crude protein and amino acid with increasing levels of fumaric acid supplementation in wheatsoybean meal based rations in pigs. It was demonstrated [66] that dietary supplementation (Figs. 2 and 3) of $0.15 \%$ of citric acid to corn-soybean meal based rations improved $(P<0.05)$ ADG $(\mathrm{g})$ and weight gain (Table. 1$)$ with a nonsignificant feed: gain ratio in pre-weaned piglets. Metzler 


\section{Feed: gain ratio}

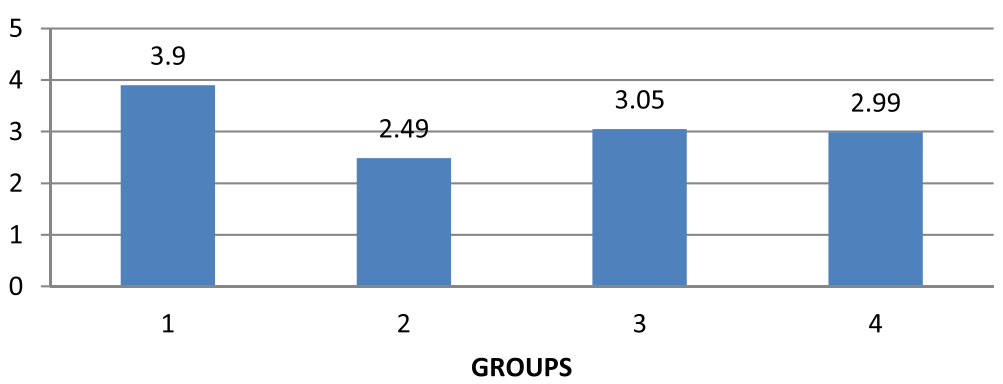

Fig 2 Effect of citric acid on feed: gain ratio of pre-weaned cross-bred piglets [Source: [66]; Suryanarayana et al.]

and Mosenthin [37] reported different apparent total tract digestibility of crude protein and energy (Table 2) and on nitrogen $(\mathrm{N})$ retention in pigs fed with various organic acids. Increased proportion of organic acids disturbs acid base balance, metabolic acidosis and decreased feed intake [29] with a reduced performance.

\section{Beneficial effects of organic acids on swine}

The anti microbial activities of organic acids differ from acid to acid depending upon concentration and $\mathrm{pH}$. As examples, Lactic acid is more effective in reducing gastric $\mathrm{pH}$ and Coliform [16, 69, 70, 71] whereas other acids like formic and propionic acids have broader range of activity on Salmonella, Coliforms and Clostridia along with fungi and yeast [17, 32, 71, 72] and are not specific. Several reports have indicated that organic acids reduce the coliform population in the gut and reduce scouring in piglets and also control post-weaning diarrhoea $[47,73]$.

\section{Microbial adaptation to acids}

Tolerance to acidic environment is recognised as an important survival strategy for many microorganisms. Recent developments in understanding this phenomenon include the identification of regulatory, as well as structural genes, involved in specific tolerance mechanisms. The unifying concept is that the microorganism under siege will sense a deteriorating environment and undergo a programmed molecular response by which specific, stress-inducible proteins are synthesised. These proteins presumably act to prevent or repair macromolecular damage caused by the stress. Some stress proteins are induced by a range of stress conditions, whereas others are induced in response to a specific stress [74]. According to [74], correlation exists between the response of enterobacteria to acid stress and pathogenecity. Kwon and Ricke [75] suggested that SCFA in the gastrointestinal tract of a host animal or in food materials might contribute to the enhancement of the virulence of $S$. typhimurium by increasing acid tolerance. Studies on acid adaptation mechanism of Streptococcus mutants [76] showed that growth at pH 5 resulted in significant changes in membrane fatty acid composition compared with cells grown at $\mathrm{pH} 7$. According to these authors, the shift in the unsaturated/saturated ratio with growth at lower $\mathrm{pH}$ suggests that changes in membrane fatty acid composition are directly related to the acid adaptive response.

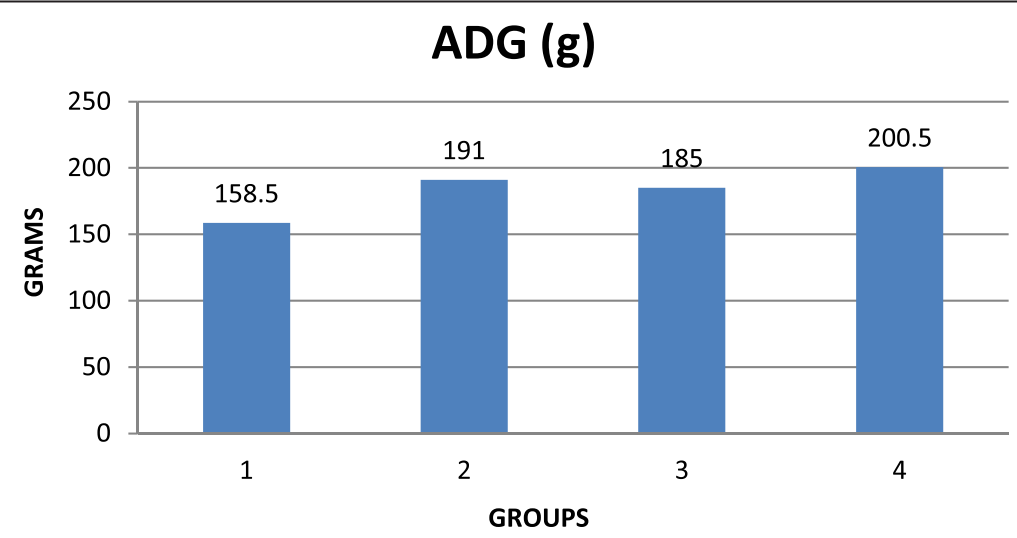

Fig 3 Effect of citric acid on ADG (g) in pre-weaned cross-bred piglets [Source: [66]; Suryanarayana et al.] 
Table 1 Effect of citric acid on growth performance of pre-weaned cross-bred piglets (Source: [66])

\begin{tabular}{lccrr}
\hline Parameter & $\mathrm{G}_{1}$ & $\mathrm{G}_{2}$ & \multicolumn{1}{c}{$\mathrm{G}_{3}$} & $\mathrm{G}_{4}$ \\
\hline Initial weight, $\mathrm{kg}$ & $4.20 \pm 0.05$ & $4.87 \pm 0.59$ & $4.78 \pm 0.29$ & $3.57 \pm 0.09$ \\
Final weight, kg & $13.40 \pm 0.88$ & $13.55 \pm 0.81$ & $13.74 \pm 0.88$ & $13.92 \pm 1.39$ \\
Total weight gain, $\mathrm{kg}$ & $9.04 \pm 0.11^{\mathrm{b}}$ & $12.42 \pm 0.07^{\mathrm{a}}$ & $11.52 \pm 0.56^{\mathrm{a}}$ & $11.99 \pm 0.32^{\mathrm{a}}$ \\
ADFl, g & $652 \pm 2.83^{\mathrm{a}}$ & $628.5 \pm 4.59^{\mathrm{a}}$ & $595.5 \pm 4.59^{\mathrm{b}}$ & $555 \pm 8.49^{\mathrm{c}}$ \\
ADG, g & $158.50 \pm 1.77^{\mathrm{b}}$ & $191 \pm 8.48^{\mathrm{b}}$ & $185 \pm 2.83^{\mathrm{b}}$ & $200.5 \pm 3.18^{\mathrm{a}}$ \\
Feed: gain ratio & $3.90 \pm 0.65$ & $2.49 \pm 0.1$ & $3.05 \pm 0.83$ & $2.99 \pm 0.71$ \\
\hline
\end{tabular}

$\mathrm{G}_{1}$ - Control; $\mathrm{G}_{2}$ - Citic acid (0.15\%); $\mathrm{G}_{3}$ - Probiotic (0.1\%); $\mathrm{G}_{4^{-}}$Citic acid (0.15 \%) \& Probiotic (0.1\%)

\section{Individual organic acids in animal nutrition Citric acid}

Citric acid is colourless and crystalline with a pleasant sour taste. This is less anti-bacterial as compared to other acids. Adding $1.5 \%$ citric acid to control diets did not significantly affect $\mathrm{pH}$, the concentration of volatile (VFA) or non-volatile fatty acids (NVFA), or microflora (total anaerobes, Lactobacilli, Clostridia, E. coli) in the contents from the stomach, jejunum, caecum or lower colon of weanling pigs [77, 78]. Moreover, the addition of $1.5 \%$ citric acid did not affect the severity or incidence of scouring after a postweaning E. coli challenge [78].

\section{Propionic acid}

Propionic acid is an oily liquid and has disagreeable rancid odour. It is produced by Propioniobacterium in the manufacture of cheese and is also one of the major end products of bacterial fermentation. In an experiment with piglets, [79] added Luprosil-NC (product contains $53.5 \%$ propionic acid) at levels of 0.3 and $1 \%$. Luprosil$\mathrm{NC}$ did not affect $\mathrm{pH}$, lactic acid concentration or SCFA concentration in the stomach and small intestine, but decreased E. coli counts in the stomach at concentrations of $1 \%$ and not at $0.3 \%$. Sutton et al. [82] studied the effect of adding $0.25 \%$ Luprosil-NC or $0.3 \%$ sodium propionate on short chain fatty acids (SCFA) concentration and Lactobacilli and E. coli counts in digesta from the stomach, duodenum, caecum and colon in 8 weeks-

Table 2 Effects of organic acids on the apparent total tract digestibility of crude protein and energy and on nitrogen (N) retention in pigs (Source: [37])

\begin{tabular}{llllllll}
\hline & Level & \multicolumn{2}{l}{ Crude protein } & \multicolumn{2}{c}{ Gross energy } & \multicolumn{2}{c}{ N retention } \\
\hline Organic acid & $(\%)$ & $\mathrm{D}(\%)$ & $\Delta \mathrm{D}$ & $\mathrm{D}(\%)$ & $\Delta \mathrm{D}$ & $\mathrm{R}(\%)$ & $\Delta \mathrm{R}$ \\
Formic acid & 1.4 & 80.6 & +1.4 & 82.2 & +0.7 & 48.3 & $+4.9^{*}$ \\
Butyric acid & 2.7 & 80.6 & +1.4 & 82.2 & $+1.6^{*}$ & 48.3 & $+4.0^{*}$ \\
Formic acid & 1.8 & 80.6 & -1.0 & 82.2 & +0.7 & 48.3 & $+2.9^{*}$ \\
Propionic acid & 2.0 & 80.2 & +2.3 & 77.9 & +1.4 & - & - \\
\hline
\end{tabular}

$D$ digestibility of non-acidified control diet, $\Delta D$ percentage unit change in the digestibility relative to the non-acidified control diet, $R \mathrm{~N}$-retention of non-acidified control diet as a percentage of intake, $\Delta R$ percentage unit change in $\mathrm{N}$-retention relative to the non-acidified control diet

*significantly different from the control diet $(P<0.05)$ old piglets. Addition of the organic acid did not significantly affect any of the parameters measured. Mathew et al. [80] added $0.25,0.5$ or $1 \%$ Luprosil-NC to a control diet, and measured $\mathrm{pH}$, numbers of $E$. coli and Lactobacilli in stomach, duodenum, caecum and colon in 8 and 12 week-old piglets. No effect of addition of the propionic acid-containing product was observed in 8 week-old piglets but 12 weeks-old piglets fed LuprosilNC showed higher Lactobacilli counts in the duodenum than those fed the control diet. EFSA [81] have reported that the maximum safe limit of Propionic acid for poultry is $10 \mathrm{~g} / \mathrm{kg}$ complete diet and for pigs it is $30 \mathrm{~g} / \mathrm{kg}$ complete diet. The corresponding safe concentrations in water for drinking would be 4 and 10 g per litre, respectively. They stated that Propionic acid, Sodium propionate and calcium propionate are authorized in EU for use in food.

\section{Fumaric acid}

Addition of fumaric acid at $1.5 \%$ level had no influence on pH, VFA concentration, and microflora (counts of total anaerobe bacteria, Lactobacilli, Clostridia, and E. coli) in the entire GI-tract $[77,78]$ in weanling piglets. The concentration of fumaric acid in the stomach and jejunum was increased when a control diet was supplemented with $1.5 \%$ fumaric acid $[77,78]$. The acid did not affect the density of Lactobacilli or E. coli along the GI-tract. Sutton et al. [82] added $0.3 \%$ Na-fumarate to a control diet, but did not see any significant effect of the acid on the concentration of SCFA and the density of Lactobacilli or E. coli along the GI-tract. The same authors observed a decreasing effect of $1 \%$ fumaric acid on E. coli counts in the stomach of 8 week-old piglets, and an increasing effect on VFA in the caecum compared to a control diet. No effect on VFA concentration, Lactobacilli counts along the GI-tract or on $E$. coli in the duodenum, caecum, or colon was detected. Studies by [83] demonstrated a significant decreasing effect of $1.8 \%$ fumaric acid on Lactobacilli in duodenum, jejunum, ileum, caecum and colon; of eubacteria in duodenum, jejunum and ileum; of enterococci in duodenum and jejunum; and of $E$. coli in the jejunum of 10 week-old piglets. Gabert and Sauer [84] fed diets containing 1.5 or $3 \%$ fumaric acid or $1.5 \%$ Na-fumarate to ileal canulated weaners. There was no 
effect of diet on the $\mathrm{pH}$ of the ileal digesta. There was a tendency for higher concentration of total SCFA in the animals fed the experimental diets as compared to animals fed the control diet.

\section{Lactic acid}

This acid is a natural constituent of some feed stuffs and also is produced by many bacteria like Lactobacillus, Streptococcus, Bifidibacterium etc. The addition of lactic acid in concentrations of $0.8 \%$ to a control weaner diet effectively reduced the levels of $E$. coli in the duodenum and jejunum of 8 weeks old piglets [23]. Thompson and Lawrence [18] measured a lower gastric $\mathrm{pH}$ when $1 \%$ lactic acid was added to drinking water and offered to gastric cannulated piglets. Furthermore, lactic acid delayed the multiplication of an enterotoxigenic E. coli and reduced the mortality rate of the animals. The supplementation of milk with $1 \%$ lactic acid resulted in lower counts of coliform bacteria and Lactobacilli in the stomach and duodenum of 2 weeks-old weaned pigs as compared to normal milk. Piglets fed diets supplemented with $0.7,1.4$ or $2.8 \%$ lactic acid also showed changes of gastrointesinal characteristics [85]. The pH in the GI-tract was reduced by the acid addition and the Lactobacilli density was reduced in the small intestine (1.4\% lactic acid) and higher in the caecum and colon ( $0.7 \%$ lactic acid) of pigs fed the diet added lactic acid.

\section{Formic acid}

Formic acid is a colourless, transparent liquid with pungent odour. Bolduan et al. [79] studied the effect of adding 0.35 or $1.2 \%$ formic acid to piglets, and observed a lower $\mathrm{pH}$ in the stomach following addition of $0.35 \%$ formic acid with no effect on SCFA concentration along the GI-tract. Roth et al. [86] fed diets supplemented with $0.6,1.2,1.8$ or $2.4 \%$ formic acid to weanling pigs and analysed digesta from the stomach, small intestine, caecum and colon. The addition of formic acid resulted in higher $\mathrm{pH}$ values in the contents of small intestine, caecum and colon. Furthermore, the concentration of lactic acid in the small intestine and the concentration of SCFA in the colon were lower as compared to animals fed the control diet. In a similar experiment with piglets, [83] observed higher numbers of coliform bacteria in the duodenum (1.8\% formic acid), lower Lactobacilli and coliform counts in the caecum and colon, and lower numbers of eubacteria in the caecum as compared to pigs fed a control diet.

Maribo et al. [85] fed piglets diets supplemented with 0.7 or $1.4 \%$ formic acid. Addition of $1.4 \%$ formic acid reduced the $\mathrm{pH}$ in the stomach, caecum and colon, with lower concentrations of lactic acid in the small intestine and higher lactic acid concentrations in the colon The concentration of formic acid in the stomach, that of acetic acid in the small intestine, and that of acetic acid and propionic acid in caecum and colon was higher in acid supplemented animals. Furthermore, the authors found lower numbers of lactobacilli in distal small intestine and caecum, lower coliform counts in the stomach ( $0.7 \%$ formic acid) and lower yeast counts along the GI-tract. The addition of Potassium diformate at concentrations of $1.8 \%$ to a weaner diet did not significantly affect the $\mathrm{pH}$ along the GI-tract, but increased the concentration of formic acid in the stomach and small intestine. A decreased number of total anaerobe bacteria, lactic acid bacteria and yeast were found along the GI-tract. The intestinal counts of coliforms were numerically but not significantly reduced [38]. Using the same product at a dose of $1.2 \%$, [63] observed a decreasing effect of the acid on the number of coliform bacteria in the duodenum, jejunum and rectum of growing finishing pigs. On the other hand, [87] observed lowered $\mathrm{pH}$ of duodenal digesta in piglets up to $65 \mathrm{~h}$ post-feeding of potassium diformate (0.9 and $1.8 \%$ ) [88] fed piglets with 0.9 or $1.8 \%$ Potassium diformate and observed a reduction of $\mathrm{pH}$, number of coliforms and Streptococci in the stomach, and a reduction of coliforms in the colon. No effect on Lactobacilli in any segment of the GI-tract was detected.

\section{Benzoic acid}

Though this acid is not approved as as an additive or preservative the supplementation of feed with benzoic acid resulted in significantly lower counts of lactic acid bacteria, Lactobacilli and yeast throughout the entire GI- tract [85]. Benzoic acid could be detected in considerable amounts in the stomach and in smaller amounts in the small intestine, indicating that benzoic acid may not be metabolised as fast as other organic acids.

\section{Conclusion}

The modern livestock enterprises are like a tussel between consumer's concern on animal and human health with an increasing demand for animal products. Organic acids and their salts were proven as potential growth promoters in weaned piglets, finishing pigs and pregnancy sows. They can also be used safely and effectively with other additives and so these are better accepted by the feed manufacturers, animal producers and public. The main mode of action of organic acids is through their antimicrobial effects, the magnitude of which is dependent on the chemical properties of the individual acid or acid salt. Several investigations have shown a strong bactericidal effect of organic acid without significantly decreasing the $\mathrm{pH}$-value in the GI-tract. Organic acids, especially butyrates and propionates also act by stimulating secretion of pancreatic enzymes. However, exact modes of action of the organic acidifiers are still to understood and in particular their action in different sections of the gastro-intestinal tract is still unclear. In a 
nutshell, organic acids can stimulate secretion of pancreatic enzymes, lower gastric $\mathrm{pH}$, inhibit pathogens, acts as an energy source during GI-tract intermediary metabolism, improves mineral utilization by chelation process, enhances apparent total tract digestibility and improves growth performance.

\section{Competing interests}

The authors declare that they have no competing interests.

\section{Authors' contributions}

Both authors read and approved the final manuscript.

Received: 27 December 2014 Accepted: 9 September 2015 Published online: 21 October 2015

\section{References}

1. Pluske JR, Hampson DJ, Williams $\mid H$. Factors influencing the structure and function of the small intestine in the weaned pig: a review. Live Prod Sci. 1997:51:215-36.

2. Brooks PH, Moran CA, Beal J, Demeckova V, Campbell A. Liquid feeding for the young piglet. In: Varley MA, Wiseman J, editors. the Weaner Pig:Nutrition and management. Wallingford. Oxon: CAB Internationa; 2003. p. $153-78$.

3. Le Dividich J, Seve B. Effects of underfeeding during the weaning period on growth, metabolism, and hormonal adjustments in the piglet. Domest Anim Endocrinol. 2000;19:63-74

4. Aumaitre A, Peineau J, Maec F. Digestive adaptation after weaning and nutritional consequences in the piglets. Pig News Info. 1995;16:73-9.

5. Close WH. Producing pigs without antibiotic growth promoters. Advances Pork Production. 2000;11:47-56.

6. Doyle ME. Alternatives to antibiotic use for growth promotion in animal husbandry. Food Research 2001: 1-17.

7. Mathew AG, Cissel R, Liamthong S. Antibiotic resistance in bacteria associated with food animals: A United states perspective of Livestock production. Food borne Pathog Dis. 2007:4:115-33.

8. Huntur PA, Dawson S, French GL, Goosens H, Hawkey PM, Kuijper EJ, et al. Anti-microbial- resistant pathogens in animals and plants: prescribing, practices and policies. J Antimicro Chemother. 2010;65:3-17.

9. Missotten JA, Michiels J, Own A, DeSmet S, Dierick NA. Fermented Liquid Feeding in pig feeding-a review. Arch Ani Nutri. 2010;64(6):437-66.

10. Canibe J, Jensen BB. Fermented and nonfermented liquid feed to growing pigs: effects on aspects of gastrointestinal ecology and growth performance. J Anim Sci. 2003;81:2019-31.

11. Canibe N, Hojberg O, Badsberg JH, Jensen BB. Effect of feeding fermented liquid feed and fermented grain on gastro-intestinal ecology and growth performance in piglets. J Anim Sci. 2007:85:2959-71.

12. Beal JD, Niven SJ, Campbell A, Brooks PH. The effect of temperature on the growth and persistence of Salmonella in fermented liquid pig. Int. J Feed Micro. 2002;79:99-104.

13. Luckstadt C, Mellor S. Holoanalysis - the acid test in pig diets. Kraftfutter Feed Magazine. 2010;1-2:18-21.

14. Easter RA: Acidification of diets for pigs. In: (Ed. W. Haresign and D.J.A. Cole). Recent Advances in Ani Nutri Butterworths, London. UK. 1988, Pp. 61-72.

15. Hill GM, Cromwell GL, Crenshaw TD, Dove CR, Ewan RC, Knabe DA, et al. Growth promotion effects and plasma changes from feeding high dietary concentrations of zinc and copper to weanling pigs (regional study). J Anim Sci. 2000;78:1010-6.

16. Tsiloyiannis VK, Kyriakis SC, Vlemmas J, Sarris K. The effect of organic acids on the control of porcine post-weaning diarrhea. Res Vet Sci. 2001;70(3):287-93

17. Partanen $\mathrm{KH}$, Morz Z. Organic acids for performance enhancement in pig diets. Nutr Res Rev. 1999;12:117-45.

18. Thompson JL, Lawrence TL. Dietary manipulation of gastric $\mathrm{pH}$ in the profilaxis of enteric disease in weaned pigs. Some field observations. Vet Rec. 1981;109:120-2.

19. Cranwell PD. The development of acid and pepsin (EC 3. 4. 23. 1) secretory capacity in the pig; the effects of age and weaning: 1 . Studies in anaesthetized pigs. Bri J Nutri. 1985;54:305-20.
20. Gaskins HR, Kelley KW. Immunology and neonatal mortality. In: Varley MA, editor. The Neonatal Pig: Development and Survival. Wallingford, Oxon: CAB International; 1995. p. 39-55.

21. Falkowski JF, Aherne FX. Fumaric and citric acid as feed additives in starter pig nutrition. J Anim Sci. 1984;58:935-8.

22. Henry RW, Pickard DW, Hughes PE. Citric acid and fumaric acid as food additives for early-weaned piglets. Anim Prod. 1985;40:505-9.

23. Cole DJA, Beal RM, Luscombe JR. The effect on performance and bacetrial flora of lactic acid, propionic acid, calcium propionate and calcium acrylate in the drinking water of the weaned pigs. Vet Rec. 1968;83:459-64.

24. Risley CR, Kornegay ET, Lindemann MD, Wood CM, Eigel WN. Effect of feeding organic acids on selected intestinal content measurements at varying times postweaning in pigs. J Anim Sci. 1992;70:196-206.

25. Schoenherr WD. Phosphoric acid-based acidifiers explored for starter diets Feedstuffs. 1994:66:40

26. Oh HK. Effect of dietary supplements on growth, nutrient digestion and intestinal morphology in monogastric animals, Ph.D. Thesis. Korea: Seoul National University; 2004

27. Mosenthin R, Sauer WC, Ahrens F, De Lange CFM, Bornholdt U. Effect of dietary supplements of propionic acid, siliceous earth or a combination of these on the energy, protein and amino acid digestibilities and concentration of microbial metabolites in the digestive tract of growing pigs. Anim Feed Sci Technol. 1992;37:245-55.

28. Kemme PA, Jongbloed AW, Mroz Z, MaĖkinen M. Apparent ileal amino acid digestibility in pigs as affected by phytate, microbial phytase, and lactic acid. J Anim Sci. 1995;73(1):173.

29. Mroz Z, Jongbloed AW, Partenen K, van Diepen JTHM, Kemme PA, Kogut J. Apparent digestibility of amino acids and balance of nitrogen and minerals as influenced by buffering capacity and organic acids in diets for growing swine. J Anim Sci. 1997;75 Suppl 1:185 Abst.

30. Jongbloed AW, Jongbloed R. he Effect of Organic Acids in Diets for Growing Pigs on Enhancement of Microbial Phytase Efficacy. ID-DLO Report no. 96009. Lelystad, The Netherlands: Insitute for Animal Science and Health; 1996.

31. Frank K. Measures to preserve food and feeds from bacterial damage. UĖ bersichten zur TierernaÈhrung. 1994;22:149-63.

32. Bosi P, Jung HJ, Han K, Perini S, Cacciavillani JA, Casini L, et al. Effects of dietary buffering characteristic and protected or unprotected acids on piglet growth, digestibility and characteristics of gut content. Asian-Aust J Anim Sci. 1999:12(7):1104-10.

33. Ravindran V, Kornegay ET. Acidification of weaner pig diets: A review. J Sci Food Agric. 1993:62:313-22.

34. Desai $D$, Patwardhan $D$, Ranade A. Acidifiers in poultry diets and poultry production. In: Luckstadt C, editor. Acidifiers in animal nutrition - A guide for feed preservation and acidification to promote animal performance. Nottingham: Nottingham University Press; 2007. p. 63-9.

35. Peadar G, Lawlor P, Lynch B, Caffrey PJ, O'Reilly JJ, O'Connell KMV, et al. Measurements of acid-binding capacity of ingredients used in pig diets. Irish Vet J. 2005:58:447-52.

36. Sciopioni R, Zaghini G, Biavati B. Researches on the use of acidified diets for early weaning of piglets. Zootechnol Nutr Anim. 1978:4:201-18.

37. Metzler B, Mosenthin R. Effects of organic acids on growth performance and nutrient digestibilities in pigs. In: Luckstadt C, editor. Acidifiers in Animal Nutrition - A Guide for Feed preservation and Acidification to Promote Animal Performance. Nottingham: Nottingham University Press; 2007. p. 39-54.

38. Canibe N, Steien SH, Overland M, Jensen BB. Effect of K-diformate in starter diets on acidity, Microbiotia, and the amount of organic acids in the digestive tract of piglet, and on gastric alterations. J Anim Sci. 2001;79:2123-33.

39. Miller BG, Phillips A, Newby TJ, Stokes CR, Burne FJ. A transient hypersensitivity to dietary antigens in the early weaned pig: factor in the aetiology of postweaning diarrhea. In: Proc $3^{\text {rd }}$ Int Seminar on Digestive Physiology of the pig. Copenhagen, Denmark: National Institute of Animal Science; 1985. p. 65-8.

40. Maxwell FJ, Stewart CS. The microbiology of the gut and the role of probiotics. In: the Neonatal Pig: Development and Survival. Wallingford Oxon: CAB International; 1995. p. 155-86.

41. Barrow PA, Fuller R, Newport MJ. Changes in themicroflora and physiology of the anteriorintestinal tract of pig weaned at 2 days with special reference to the pathogenesis of diarrhea. Infect Immun. 1977;18:586-95 
42. Fuller $\mathrm{R}$. The importance of lactobacilli in maintaining normal microbial balance in the crop. Br Pout Sci. 1977;18:89-94.

43. Lambert RJ, Stratford M. Weak acid preservatives: modeling microbial inhibition and response. J Applied Microbiol. 1999:86:157-64.

44. Gauthier R; Intestinal health, the key to productivity - the case of organic acids. IASA XXVII convencion ANECA-WPDC. 2002, Puerto Vallarta, Jal. Mexico.

45. Biagi G, Piva A, Hill T, Schneider DK, Crenshaw TD. Low buffering capacity diets with added organic acids as substitute for antibiotics in diets for weaned pigs. In: Ball $R$, editor. Proceedings of the $9^{\text {th }}$ International Symposium on digestive Physiology in pigs. Edmonton, Banff, Alberta, Canada: University of Alberta, Department of Agriculture, Food and Nutritional Science; 2003. p. 217-9.

46. Partenen K. Organic acids-their efficacy and modes of action in pigs. In: Piva A, Bach Knudsen KE, Linndberg JE, editors. Gut Environment of pigs. Nottingham: Nottingham University Press; 2001. p. 201-18.

47. PapatsirosVG TPD, Tzika ED, Papaioannou DS, Petridou E, Alexopoulos C, Kyriakis SC. Effect of benzoic acid and combination of benzoic acid with probiotic contatining Bacillus cereus var. toyoi in weaned pig nutrition. J Vet Sci. 2011;14(1):117-25.

48. Pinheiro V,Mourao JL, Alves A, Rodrigues M, Saavedra MJ: Effect of Zinc bacitracin on the performance,digestibility and caecal development of growing rabbits. In: Proceedings of the $8^{\text {th }}$ world rabbit congress, Puebla, Mexico, 2004, pp 942-947.

49. Stonerock R. Possibilities of Salmonella control with the aid of acidifiers. In: Luckstadt C, editor. Acidifiers in Animal Nutrition - A Guide for Feed preservation and Acidification to Promote Animal performance. Nottingham: Nottingham University Press; 2007. p. 21-9.

50. Giesting DW, Easter RA. Response of starter pigs to supplementation of corn soybean meal diets with organic acids. J Anim Sci. 1985;60(5):1288-94.

51. Kirchegessner M, Roth FX. Fumaric acid as a fed additive in pig nutrition. Pig News Info. 1982;3:259.

52. Blank R, Mosenthin R, Sauer WC, Huang S. Effect of fumaric acid and dietary buffering capacity on heal and fecal amino acid digestibilities in earlyweaned pigs. J Anim Sci. 1999;77:2974-84

53. Liem A, Pesti GM, Edwards Jr HM. The effect of several organic acids on phytate phosphorus hydrolysis in Broiler chicks. Poult Sci. 2008;87(4):689-93.

54. Jongbloed AW: In: Phosphorus in the feeding of pigs. Agricultural University of Wageningen. 1987, P. 343.

55. Jongbloed AW, Mroz Z, van der Weij-Jongbloed R, Kemme PA. The effects of microbial phytase, organic acid and their interaction in diets for growing pigs. Livest Prod Sci. 2000;67:113-22.

56. Boling SD, Webel DM, Mavromichalis I, Parsons CM, Baker DH. The effects of citric acid on phytate-phosphorus utilization in young chicks and pigs. J Anim Sci. 2000;78:682-9.

57. Hohler D, Pallauf J. Effect of Zn supply and addition of citric acid to a maize-soya diet on the nutritive value and mineral absorption in piglets. J Anim Physio Anim Nutri. 1994;71:189-99.

58. Hohler D, Pallauf J. Effect of citric acid added to a maize-soya diet with or without Zn supplementation on the availability of minerals. J Anim Physio Anim Nutri. 1993;69:133-42.

59. Harada E, Kiriyama H, Kobayashi E, Tsuchita H. Postnatal development of biliary and pancreatic exocrine secretion in piglets. Comparative Biochem Physiol. 1988;91:43-51.

60. Sakata T. Stimulatory effect of short chain fatty acids on epithelial cell proliferation in the rat intestine: A possible explanation for trophic effects of fermentable fibre, gut microbes and luminal trophic factors. Br J Nutr. 1987;58:95-103.

61. Sakata T, Adachi M, Hashida M, Sato N, Kojima T. Effect of n-butyric acid on epithelial cell proliferationof pig colonic mucosa in short-term culture. Dtsch Tieraerztl Wochenschr. 1995;102:163-4.

62. Galfi P, Bokori J. Feeding trial in pigs with a diet containing sodium n-butyrate. Acta Vet Hung. 1990;38:3-17.

63. Overland M, Granli T, Kjos NP, Fjetland O, Steien SH, Stokstad M. Effect of dietary formats on growth performance, carcass traits, sensory quality, intestinal microflora, and stomach alterations in growing-finishing pigs. J Anim Sci. 2000;78:1875-84.

64. Øverland M, Bikker P, Fledderus J. Potassium diformate in the diet of reproducing sows: Effect on performance of sows and litters. Livestock Sci. 2009;122:241-7.
65. Lückstädt C. Effects of dietary potassium diformate on feed intake, weight loss and back fat reduction in sows: pre-farrowing till weaning. Adv Anim Biosci. 2011;2(1):145.

66. Suryanarayana MVAN, Suresh J, Rajasekhar MV. A study on the associated effect of probiotic and citric acid on the performance of pre-weaned piglets. Tamilnadu J Vety Anim Sci. 2012;8(3):126-30.

67. Suryanarayana MVAN, Ravi A, Suresh J. Effect of dietary supplementation of Sodium formate on the performance and carcass characteristics of cross-bred pigs. Indian J Anim Nutr. 2010;27(4):411-4.

68. Gabert VM, Sauer WC. The effect of fumaric acid and sodium fumarate supplementation to diets for weanling pigs on amino acid digestibility and volatile fatty acid concentrations in ileal digesta. Anim Feed Sci Technol. 1995:53:243-54.

69. Jensen BB, Mikkelsen LL, Canibe N, Hoyberg O. Salmonella in slaughter pigs Annual report 2001 of The Danish Institute of Agricultural Sciences. Denmark: Research Centre Foulum, Tjele; 2001. p. 23.

70. Bosi P, Sarli G, Casini L, De Philippi S, Trevisi P, Mazzoni M, et al. Effect of dietary addition of free or fat protected calcium formate on growth, intestinal morphology and health of E Coli 88 challenged weaning pigs. Ital J Anim Sci. 2005;4(2):452-4.

71. Øverland $M$, Kjos NP, Borg M, Sorum H. Organic acids in diets for entire male pigs. Livest Prod Sci. 2007;109(1-30):170-3.

72. Creus E, Perez JF, Peralta B, Baucells F, Mateu E. Effect of acidified feed on the prevelance of Salmonella in market age pigs. Zoonoses Public Health. 2007;54(8):314-9.

73. Piva A, Casadei G, Biagi G. An organic acid blend can modulate swine intestinal fermentationand reduce microbial proteolysis. Can J Anim Sci. 2002;82(4):527-32.

74. Bearson S, Bearson B, Foster JW. Acid stress responses in enterobacteria. FEMS Microbiol Letters. 1997;147:173-80.

75. Kwon YM, Ricke SC. Induction of acid resistance of Salmonella typhimurium by exposure to short-chain fatty acids. Appl Environ Microbiol. 1998;64:3458-63.

76. Quivey RG, Faustoferri R, Monahan K, Marquis R. Shifts in membrane fatty acid profiles associated with acid adaptation of Streptococcus mutans. FEMS Microbiol Letters. 2000;189:89-92.

77. Risley CR, Kornegay ET, Lindemann MD, Weakland SM. Effects of organic acid with and without a microbial culture on performance and gastrointestinal tract measurements of weanling pigs. Anim Feed Sci Technol. 1991;35:259-70.

78. Risley CR, Kornegay ET, Lindemann MD, Wood CM, Eigel WN. Effect of feeding organic acids on gastrointestinal digesta measurements at various times postweaning in pigs challenged with enterotoxigenic Escherichia coli. Canadian J Anim Sci. 1993;1993(73):931-40.

79. Bolduan VG, Jung $H$, Schneider R, Block J, Klenke B. Influence of propionic- and formic acid on piglets. J Anim Phy Anim Nutri. 1988;59:72-8.

80. Mathew AG, Sutton AL, Scheidt A, Bforsyth DM, Patterson JA, Kelly DT: Effects of a propionic acid containing feed additive on performance and intestinal microbial fermentation of the weanling pig. In: Proceedings of the 5 th International Symposium on Digestible Physiology in pigs. Wageningen, Netherlands, 24-26 April 1991,Eaap Publication No. 54: 464-69.

81. EFSA Panel on additives and products or substances used in animal feeds (FEEDAP) Panel members 2011, 9 (12) 2246 (22 pages).

82. Sutton AL, Mathew AG, Scheidt AB, Patterson JA, Kelly DT: Effects of carbohydrate sources and organic acids on intestinal microflora and performance of the weanling pig. In: Proceedings of the 5 th International Symposium on Digestible Physiology in pigs. Wageningen, Netherlands, 24-26 April 1991, Eaap Publication No. 54: 422-27.

83. Gedek B, Roth FX, Kirchgessner M, Wiehler S, Bott A, Eidelsburger U. Influence of fumaric acid, hydrochloric acid, sodium formate, Tylosin and Toyocerin on the microflora in different segments of the gastrointestinal tract. 14. Communication. Investigations about the nutritive efficacy of organic acids in the rearing of piglets. J Anim Physio Anim Nutri. 1992;68:209-17.

84. Gabert VM, Sauer WC. The effects of supplementing diets for weanling pigs with organic acids.A review. J Anim Feed Sci. 1994;3:73-87.

85. Maribo $H$, Jensen BB, Hedemann MS : Different doses of organic acids to piglets. Danish Bacon and Meat Council 2000, no. 469.

86. Roth FX, Eckel B, Kirchgessner M, Eidelsburger U. Influence of formic acid on $\mathrm{pH}$-value, dry matter content, concentration of volatile fatty acids and lactic acid in the gastrointestinal tract. 3. Communication: Investigations about 
the nutritive efficacy of organic acids in the rearing of piglets. J Anim Physio Anim Nutri. 1992;67:148-56.

87. Mroz Z, Jongbloed AW, Von Der Weij-Jongbloed R, Øverland M :Effects of adding potassium diformate and phytase excess for weaned piglet:In Digestive physiology of pigs, Ed. by Lindberg J E, Ogle B, CABI publishing 2001, p 305-7.

88. Février C, Gotterbarm G, Jaghelin-Peyraud Y, Lebreton Y, Legouevec F, Aumaitre $\mathrm{A}$ : Effects of adding potassium diformate and phytase excess for weaned piglet: In Digestive physiology of pigs, Ed. by Lindberg J E, Ogle B, CABI publishing 2001, pp 136-38.

Submit your next manuscript to BioMed Central and take full advantage of:

- Convenient online submission

- Thorough peer review

- No space constraints or color figure charges

- Immediate publication on acceptance

- Inclusion in PubMed, CAS, Scopus and Google Scholar

- Research which is freely available for redistribution 